\title{
GENETIC POLYMORPHISM OF SOME MICROSATELLITES ON CHROMOSOME SEVEN IN THE EGYPTIAN BUFFALO
}

\author{
M. S. Hassanane ${ }^{1}$, A. A. Zaki ${ }^{2}$, S. Abou-Bakr ${ }^{2}$, R. R. Sadek ${ }^{2}$ and A. A. \\ Nigm $^{2}$
}

1- Cell Biology Department, National Research Center, Giza, Egypt, 2- Department of Animal Production, Faculty of Agriculture, University of Cairo

\section{SUMMARY}

Five bovine microsatellites were tested in the Egyptian buffalo genome to determine the amplification as well as the number of alleles if amplification was successful. These microsatellites, BM143, TGLA37, FBN13, ILSTS035 and ILSTS093 were tested in 70 lactating Egyptian buffaloes. All microsatellites tested amplified the buffalo DNA and produced a PCR product. Characterization of the PCR products on polyacrylamide gels revealed that three of the microsatellites tested were monomorphic (TGLA37, FBN13, ILSTS035), while the other two were polymorphic (BM143, ILSTS093). BM143 microsatellite had nine alleles with size ranging from 99 and $135 \mathrm{bp}$. Allele frequency ranged from 0.015 to 0.431 . ILSTS093 showed eight alleles ranging in size from 193 to $217 \mathrm{bp}$ with allele frequency ranging between 0.009 and 0.293 . The results obtained indicated the successful genotyping of bovine microsatellites in the buffalo genome and suggested that some cattle microsatellites can be a valuable source for genome analysis in the Egyptian buffalo.

Keywords: Egyptian buffalo, chromosome 7, microsatellites, polymorphism

\section{INTRODUCTION}

The Egyptian buffalo has been an integral part of livestock agriculture in Egypt for over 1200 years (Bhat, 1992) producing milk, meat, leather, manure, and draft power for agricultural operations. Today, about four million buffaloes are raised in Egypt, providing 2.3 million tons of milk and 270,000 tons of meat annually (FAOSTAT, 2005). Moreover, the buffalo plays a vital role in socioeconomic life of farmers in Egypt.

Microsatellite markers are powerful research tools but their development is labor intensive and costly. Consequently, researchers have tried to use microsatellite markers developed from one species in another (Moore et al., 1991). Microsatellite markers developed for Bos taurus have been successfully used in closely related species (buffalo: Bubalus bubalis) (Navani et al., 2002 and Soysal et al., 2005)

Despite the great advances in genomic technology observed in several animal species, the availability of molecular tools such as microsatellite markers typing or characterization is limited in the Egyptian buffalo where few studies were performed.

The aim of the present study was to investigate the polymorphism, the number and sizes of the obtained alleles for some bovine microsatellites in the buffalo 
chromosome 7 equivalent to chromosome 6 in cattle, namely, BM143, TGLA37, FBN13, ILSTS093 and ILSTS035.

\section{MATERIALS AND METHODS}

\section{Blood sample collection and DNA extraction}

Blood samples were collected from 70 lactating unrelated buffaloes from the herd maintained at the Agriculture Experimental Station, Faculty of Agriculture, Cairo University. Blood was collected in $10 \mathrm{ml}$ tubes containing EDTA as an anticoagulant matter. The samples were kept at $4{ }^{\circ} \mathrm{C}$ and processed for DNA extraction in a period not exceeding 3 days from its arrival to the laboratory. DNA was extracted and purified using the standard Phenol-Chloroform technique described by Sambrook et al. (1989). DNA concentration was measured on U.V. spectrophotometer at a wave length of $260 \mathrm{~nm}$.

\section{PCR run with specific microsatellite primers:}

All microsatellites chosen were located in cattle chromosome 6 which are correlated with milk yield and constituents in cattle (Georges et al., 1995; Spelman et al., 1996; Freyer et al., 2002; Olsen et al., 2002; Freyer et al., 2003; Freyer et al., 2004; Peter et al., 2005; Schnabel et al., 2005 and Chen et al., 2006;). Details of these microsatellites are presented in Table (1).

Table 1. Details of microsatellites chosen in cattle chromosome 6

\begin{tabular}{|c|c|c|}
\hline Microsatellite & Primer sequence & Reference \\
\hline BM143 & $\begin{array}{l}\text { ACCTGGGAAGCCTCCATATC } \\
\text { CTGCAGGCAGATTCTTTATCG }\end{array}$ & $\begin{array}{l}\text { Bishop et al., } \\
1994\end{array}$ \\
\hline TGLA37 & $\begin{array}{l}\text { CATTCCAATCCCCTATCCTGAG } \\
\text { TGAATGATTCTATGAAGACCTGTA }\end{array}$ & $\begin{array}{l}\text { Yoneda et al., } \\
1999\end{array}$ \\
\hline FBN13 & $\begin{array}{l}\text { ACTTTCATTAGATTGCTGCAAATAG } \\
\text { AAATATGGAAACGACCTGTGG }\end{array}$ & $\begin{array}{l}\text { Weikard et al., } \\
1995\end{array}$ \\
\hline ILSTS093 & $\begin{array}{l}\text { TGAAATATACCTGAGTAGCAGC } \\
\text { TTGTTTTAACTCCCCACCCC }\end{array}$ & $\begin{array}{l}\text { Kemp et al., } \\
1995\end{array}$ \\
\hline ILSTS035 & $\begin{array}{l}\text { TTGACCATAACAGCTACTCC } \\
\text { TAGGTCCATGAATCACAGGG }\end{array}$ & $\begin{array}{l}\text { Kemp et al., } \\
1995\end{array}$ \\
\hline
\end{tabular}

Polymerase chain reaction (PCR) was carried out on $50 \mathrm{ng}$ of genomic DNA in a $25 \mu \mathrm{l}$ reaction of $50 \mathrm{mM} \mathrm{KCl}, 10 \mathrm{mM}$ Tris- $\mathrm{HCl}(\mathrm{pH} \mathrm{8.3),} 200 \mu \mathrm{M}$ dNTP, $1.5 \mathrm{mM}$ $\mathrm{MgCl}_{2}, 1 \mathrm{mM}$ tetra-ammonium-chloride, $0.1 \%$ Triton $\mathrm{X}-100,0.01 \%$ gelatin, $4.5 \mathrm{pmol}$ of each primer and $0.25 \mathrm{U}$ Taq DNA polymerase. The standard PCR run cycle was usually as: primary denaturation: $95{ }^{\circ} \mathrm{C}$ for 3 minute then 35 cycles as: $95{ }^{\circ} \mathrm{C}$ for 15 sec.; $55-60{ }^{\circ} \mathrm{C}$ for $30-60 \mathrm{sec}$; $72^{\circ} \mathrm{C}$ for $30 \mathrm{sec}$, final extension: $72{ }^{\circ} \mathrm{C}$ for 5 minute and storage: $15{ }^{\circ} \mathrm{C}$ forever. The success of the PCR was detected on $2 \%$ agarose after running in a horizontal electrophoresis set and staining with ethidium bromide. For 
optimization the PCR, the temperature and time of annealing temperature were changed.

The products of the successful PCR were characterized under denaturing conditions on $12 \%$ polyacrylamide vertical electrophoresis (Sambrook et al., 1989). After the end of the run, the gel was stained in an ethidium bromide solution $(0.5 \mu \mathrm{g}$ $/ \mathrm{ml}$ TBE buffer). The gel image was captured electronically using Biometra gel documentation system. The allele sizes were determined using free software named Lab. image V2.7. It is dispersed free from Proland company (Germany), from the internet through the web page: http://www.labimaging.com/servlet/engine/home/ start.html.

\section{RESULTS AND DISCUSSION}

The results of the prescreening by running the PCR products on $2 \%$ agarose gel electrophoresis were used to test the success of amplification. All microsatellites tested amplified the buffalo DNA and produced a PCR product. The PCR products were subjected to characterization on vertical polyacrylamide gel for identification of the polymorphism as well as the number and sizes of alleles if polymorphism is present.

The results showed that only two microsatellites tested were polymorphic (BM143; ILSTS093) meaning that they could be used further in parentage and QTL mapping studies. While the other three were monomorphic (TGLA37; FBN13; ILSTS035).

\section{Polymorphic microsatellites:}

BM143:

Figure (1) shows the characterization of microsatellite BM143 products on polyacrylamide gel.

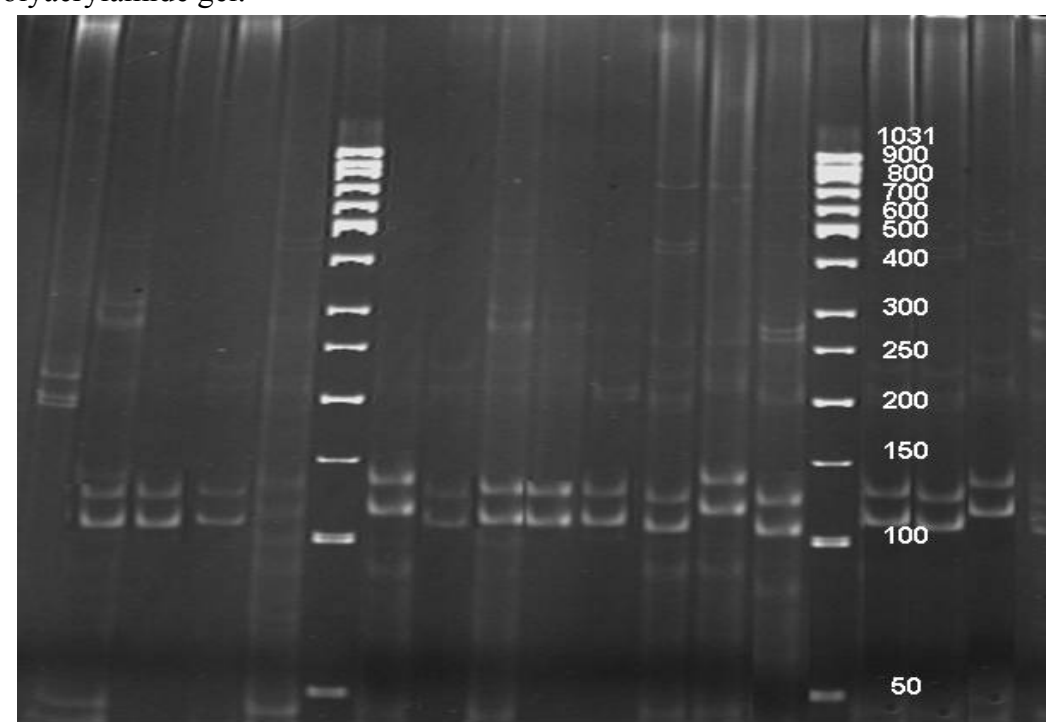

Fig. 1 Ethidium bromide stained polyacrylamide gel for the two separated alleles of microsatellite BM143 after running vertically 
In general, this microsatellite showed totally nine alleles. The minimum allele size was $99 \mathrm{bp}$ while the maximum was $135 \mathrm{bp}$. The frequencies of these alleles ranged from 0.015 to 0.431 . The observed allele sizes of the BM143 microsatellite marker and their frequencies in the population under study are presented in Table (2).

Table 2. The observed allele size of BM143 microsatellite marker and their frequencies in the population under study

\begin{tabular}{ccc}
\hline Allele number & Allele size (bp) & Allele frequency \\
\hline 1 & 99 & 0.031 \\
2 & 105 & 0.030 \\
3 & 109 & 0.431 \\
4 & 115 & 0.023 \\
5 & 119 & 0.015 \\
6 & 121 & 0.023 \\
7 & 125 & 0.408 \\
8 & 131 & 0.023 \\
9 & 135 & 0.015 \\
\hline
\end{tabular}

The highest allele frequency was observed for the allele no 3 (109 bp) with a frequency of 0.431 . While alleles no $5,9(119,135 \mathrm{bp})$ were the lowest allele frequencies observed (0.015).

The observed heterozygosity was 1.00 and the expected heterozygosity was 0.644 . Accordingly, the value of the expected heterozygosity was very high and the value of the observed heterozygosity was higher than the expected heterozygosity indicating much of genetic variability between individuals. Unfortunately, no previous studies for this marker were conducted on the buffalo genome. On the other hand, this microsatellite was reprted to be polymorphic in cattle and produced many alleles (Bishop et al., 1994; Kappes et al., 1997; Ron et al., 2001; Olsen et al., 2004; Baruch et al., 2006 and D'Angelo et al., 2006).

Previous analysis of BM143 marker in cattle (Bos taurus) agreed with our results. Bishop et al. (1994) tested this marker in four breed crosses consisting of Gelbvieh, Simmental, Nellore, Hereford, Angus and Brahman. Crosses were designed to maximize heterozygosity of one or both parents and obtain samples of diverse gene pools. Also, Olsen et al. (2004) studied this marker in Norwegian dairy cattle breeds. They found that there were 13 alleles ranging in size between 90 and 122 bp. BM143 marker was studied likewise by Baruch et al. (2006) in the Israeli Holstein cattle where 13 alleles were found ranging in fragment length from 90 to 118 bp. Moreover, Bishop et al. (1994); Kappes et al. (1997); Ron et al. (2001) and D'Angelo et al. (2006) reported that this microsatellite was polymorphic in cattle.

BM143 microsatellite marker was not only studied in bovidae species but also in ovine and caprine species such as sheep and goats (De Gortary et al., 1997 and Maudet et al., 2004). The number of observed alleles ranged from 3 to 4 and allele size ranged from 102 to $128 \mathrm{bp}$ in crosses came from three sheep breeds (Romanov, Rambouillet and Suffolk). Also, BM143 marker was analyzed in six indigenous Spanish sheep breeds Churra, Latxa, Manchega, Rasa-Aragonesa, Castellana and Merino by Arranz et al. (2001). The authors found that there were 11 alleles in 
Churra and Latxa breeds, 10 alleles in Manchega and Merino breeds, 9 alleles in Rasa-Aragonesa breed and 6 alelles in Castellana breed. In goats, there were 9 alleles, and allele size ranged between 93 and 121 bp (Maudet et al., 2004).

\section{ILSTS093:}

Microsatellite ILSTS093 was shown to be, also, a polymorphic. Figure (2) shows the characterization of its products on polyacrylamide gel.

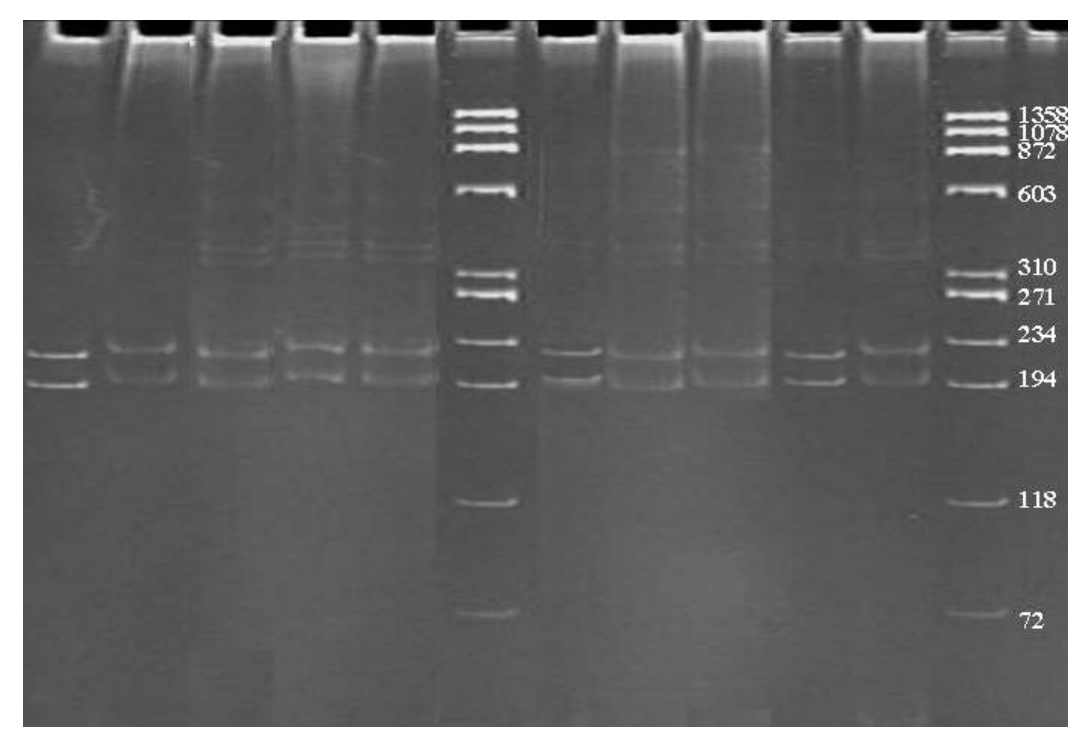

Fig. 2 Ethidium bromide stain for the two separated alleles of ILSTS093 marker, run vertically on polyacrylamide gel electrophoresis.

In general, this microsatellite showed a total of eight alleles. The minimum allele size was $193 \mathrm{bp}$ while the maximum allele size was $217 \mathrm{bp}$. The frequencies of these alleles ranged from 0.009 to 0.293 . The observed allele size of the ILSTS093 microsatellite marker and their frequencies in the population under study are presented in Table (3).

All animals under study were heterozygotes, accordingly, the observed heterozygosity was 1.00 and the expected heterozygosity was 0.789 . Alleles no 1 and $5(193,207 \mathrm{bp})$ were the least frequent (0.009). While allele no 7 (213 bp) was the most frequent allele $(0.293)$.

No previous studies for this allele were conducted on the river buffalo. ILSTS093 microsatellite was monomorphic in the African buffalo (Syncerus caffer) (Van Hooft et al., 1999) and gave only one allele with the size of 166 bp. Navani et al. (2002) tested this marker in Indian buffalo (Murrah, Nili-Ravi and Mehsana breeds) but no amplification happened.

Previous analysis of ILSTS093 marker in cattle (Bos taurus) agreed with our results. Kemp et al. (1995) reported 8 alleles in cattle with a size range from 193 to 207 bp. Ma et al. (1996) tested this marker in four beef breeds of cattle (Angus, 
Devon, Gelbvieh, Simmental) and found that, there were 11 alleles ranging in size from 186 to $212 \mathrm{bp}$. Vallejo et al. (2003) reported seven alleles in Holstein cattle. These differences in number of alleles are due to the type of cattle breed studied and the genetic polymorphism within the breed itself.

Table 3. The observed allele sizes of ILSTS093 microsatellite marker and their frequencies in the population understudy

\begin{tabular}{ccc}
\hline Allele number & Allele size (bp) & Allele frequency \\
\hline 1 & 193 & 0.009 \\
2 & 195 & 0.094 \\
3 & 199 & 0.292 \\
4 & 203 & 0.094 \\
5 & 207 & 0.009 \\
6 & 209 & 0.104 \\
7 & 213 & 0.293 \\
8 & 217 & 0.104 \\
\hline
\end{tabular}

Monomorphic Markers

ILSTS035:

Figure (3) shows the result of the amplification after running the product on $2 \%$ agarose and staining with ethidium bromide.

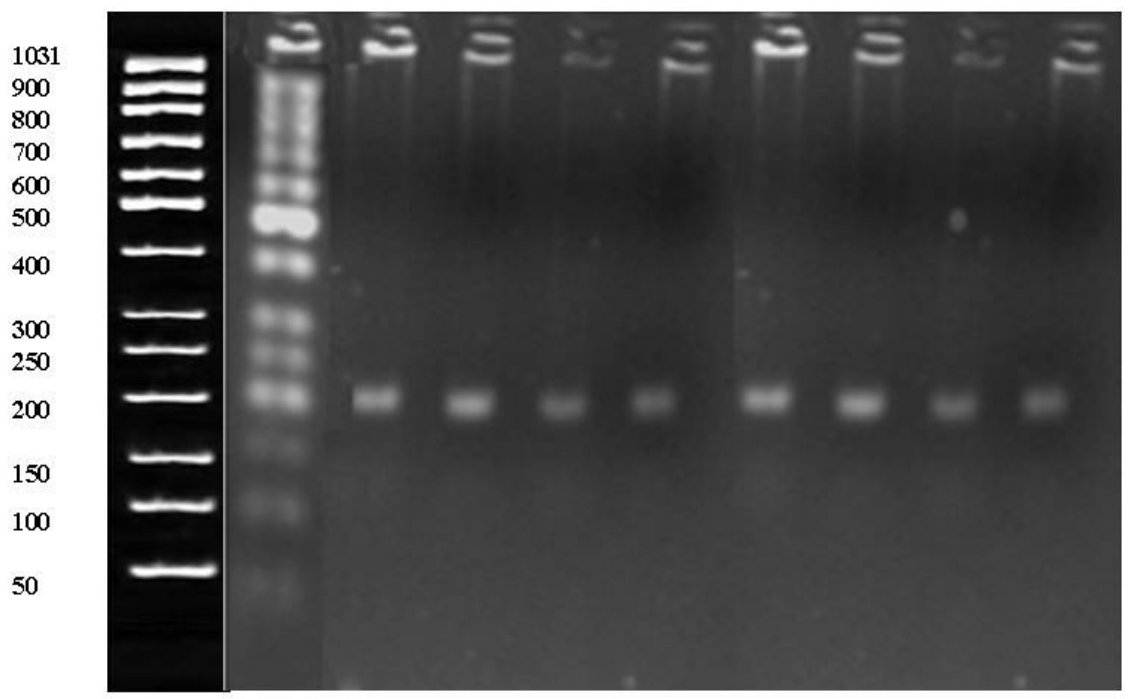

Fig. 3 Ethidium bromide stained agarose gel for the PCR product of microsatellite ILSTS035 after running horizontally

Characterization of the PCR products on polyacrylamide gel revealed the presence of only one allele with 189 bp size length. Figure (4) shows the ethidium bromide stained for the polyacrylamide gel. Monomorphic markers probably reflect the absence of allelic variation rather than primer slippage (Hayden and Sharp, 2001). 


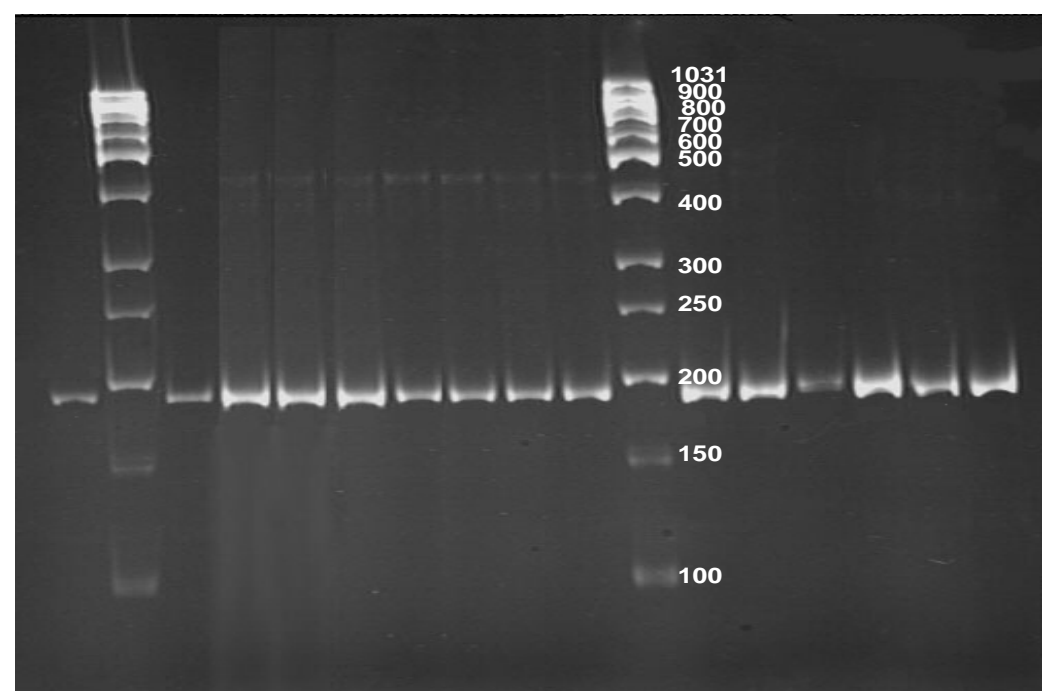

Fig. 4 Ethidium bromide stained polyacrylamide gel for the ILSTS035 microsatellite after running vertically

Our results for this marker agree with those reported by Navani et al. (2002) after testing it on Murrah, Nili-Ravi and Mehsana Indian river buffalo breeds, the authors found it monomorphic microsatellite with allele size of $145 \mathrm{bp}$. Moreover, Van Hooft et al. (1999) found that this microsatellite was also monomorphic when typed in African buffalo (Syncerus caffer), with allele size 186 bp.This microsatellite was shown to be polymorphic in cattle. Ma et al. (1996) after typing it in four beef breeds of cattle (Angus, Devon, Gelbvieh and Simmental), found that it produced 9 alleles with a size range: 236-266 bp. Vallejo at al. (2003) reported 5 alleles for it in the North American Holstein cattle. Yeo et al. (2004) observed nine alleles for it with a size range from 210 to $266 \mathrm{bp}$ in Hanwoo Korean cattle. The authors used this microsatellite to detect and locate quantitative trait loci (QTL) for traits in Hanwoo cattle. Likewise, nine alleles were recorded for this marker in Chinese Holstein cattle in a study of quantitative trait loci affecting milk production traits on cattle chromosome 6 by the daughter design (Chen et al., 2006).

This microsatellite cross hybridized with sheep genome and it was found to be also monomorphic giving one allele with a size 191 bp. (De Gortary et al., 1997).

Results of the amplification of the bovine microsatellite in buffalo and sheep genomes may be referring to the sharing of a common ancestry for cattle, buffalo and sheep after the divergence of subfamily Bovinae (Bos taurus) from the family Bovidae (Mattapallil and Ali, 1999). 


\section{TGLA37:}

Figure (5) shows the results of the amplification after running the product on $2 \%$ agarose and staining with ethidium bromide.

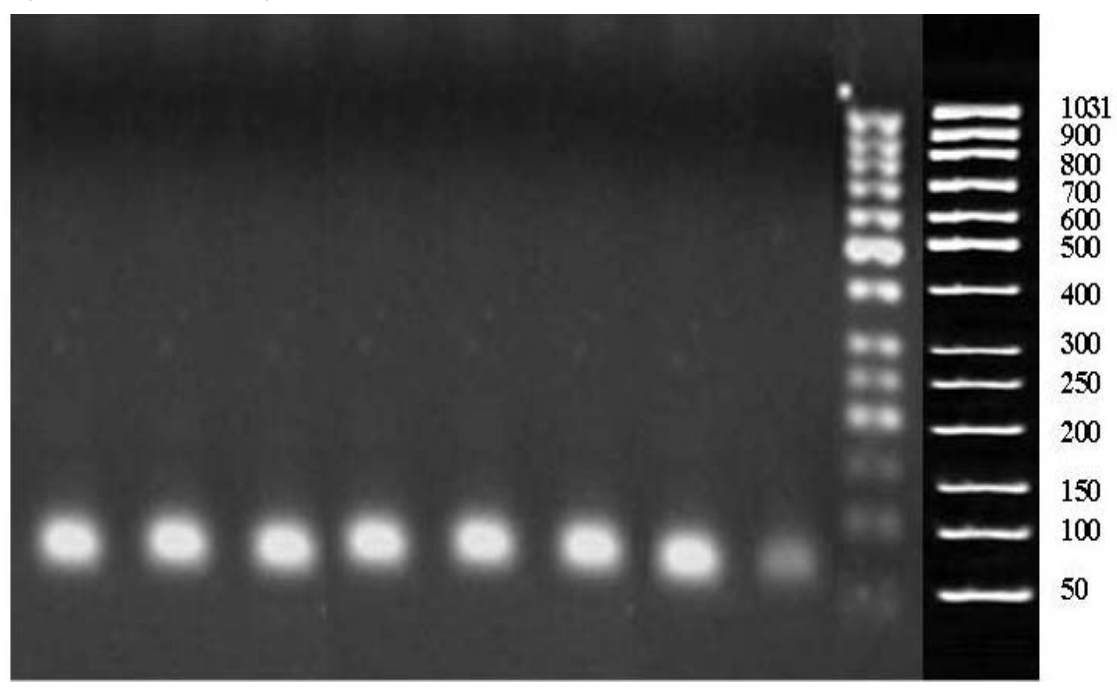

Fig. 5 Ethidium bromide stained agarose gel for the PCR product of microsatellite TGLA37 after running horizontally

Characterization of the PCR products on polyacrylamide gel revealed the presence of only one allele with 86 bp size length. Figure (6) shows the ethidium bromide stained for the polyacrylamide gel.

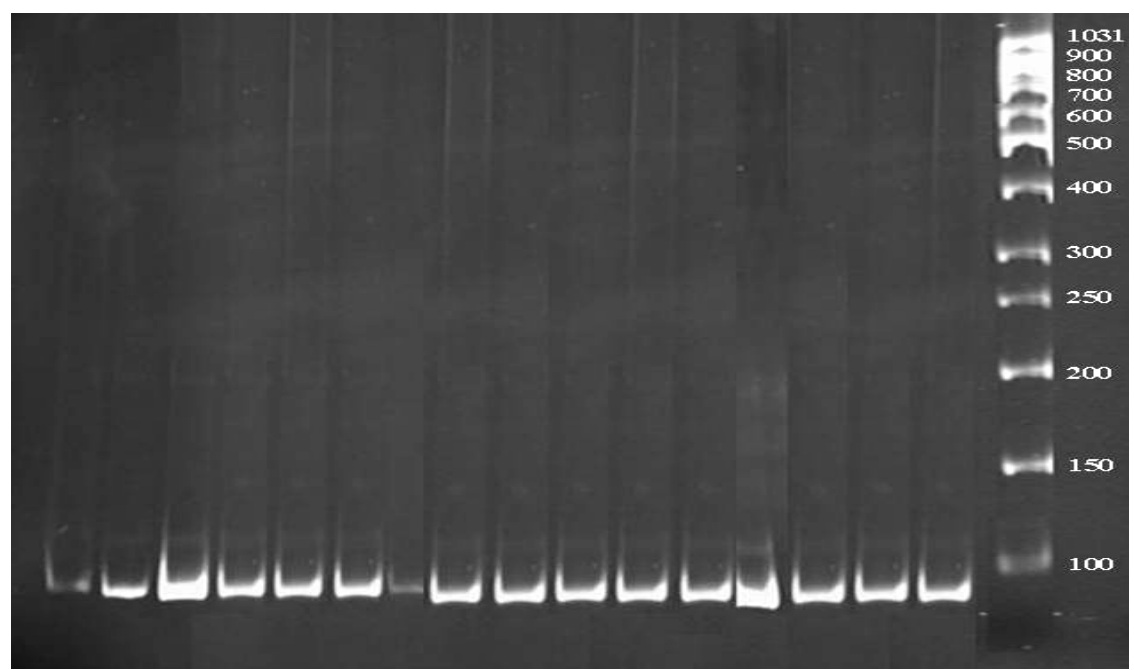

Fig. 6 Ethidium bromide stained polyacrylamide gel for the TGLA 37 microsatellite after running vertically 
No previous studies were conducted with this microsatellite on buffalo to compare with our results. In contrast, Georges and Massey (1992); Georges et al. (1995) and Ihara et al. (2004) found that, there were 5 observed alleles, their size ranging between 108 to $126 \mathrm{bp}$ in American Holstein cattle.

Several of the previous studies have indicated the presence of a QTL variously affecting milk yield and milk traits on cattle chromosome 6 located near marker TGLA37. QTL were found between markers BM1329 and TGLA37, as well as in the interval between TGLA37 and FBN13 in American Holsteins (Georges et al., 1995), Dutch Holsteins (Spelman et al., 1996), German Holsteins (Freyer et al., 2002; and Freyer et al., 2004). In addition, Freyer et al. (2003) found that there was highly significant impact of TGLA37 marker on fat yield of milk in German Holstein Friesian.

\section{FBN13:}

Figure (7) shows the results of the amplification after running the product on $2 \%$ agarose and staining with ethidium bromide.

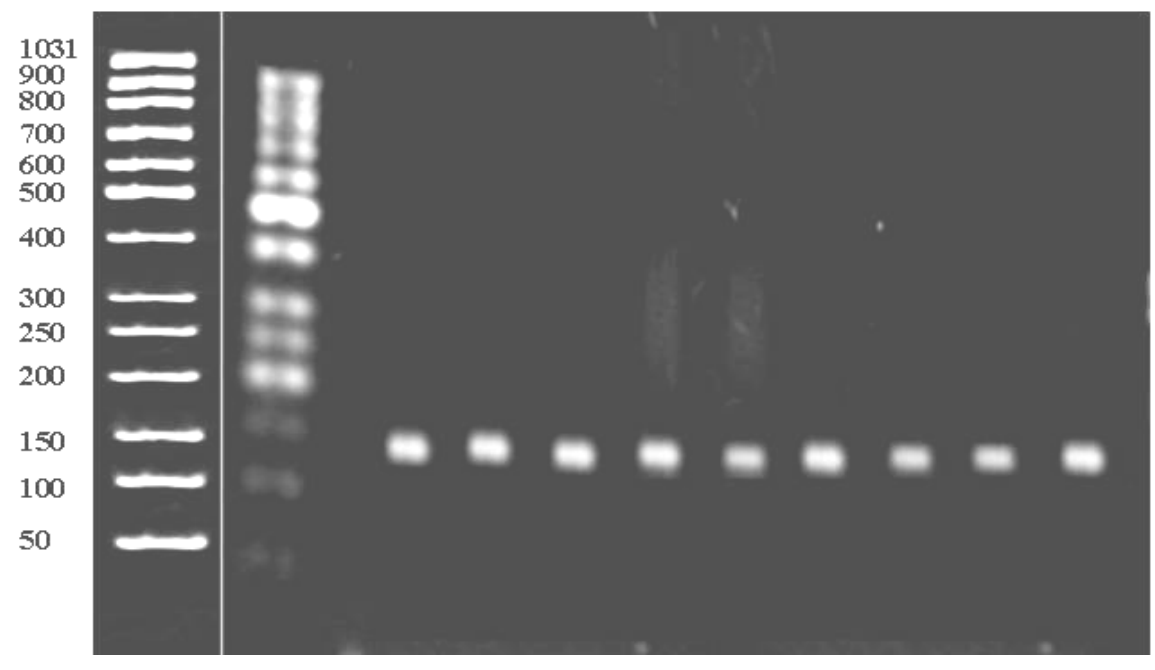

Fig. 7 Ethidium bromide stained agarose gel for the PCR product of microsatellite FBN13 after running horizontally

The characterization of the PCR products on polyacrylamide gel revealed the presence of only one allele with $140 \mathrm{bp}$ size length. Figure (8) shows the ethidium bromide stained for the polyacrylamide gel.

Limited studies regarding typing this microsatellite were conducted in cattle. Olsen et al. (2004) reported that, FBN13 was a polymorphic marker and gave nine alleles in American Holstein Cattle. Studies on this marker indicated the presence of a QTL affecting milk fat and protein percentage in the interval between FBN9 and FBN13 in Norwegian dairy cattle (Olsen et al., 2002). In addition, Freyer et al. (2004) obtained a significant QTL between TGLA37 and FBN13 for protein yield of 
milk in German Holstein-Friesian. Likewise, FBN13 marker had highly significant effect on milk yield traits (Peter et al., 2005) in German Holstein-Friesian.

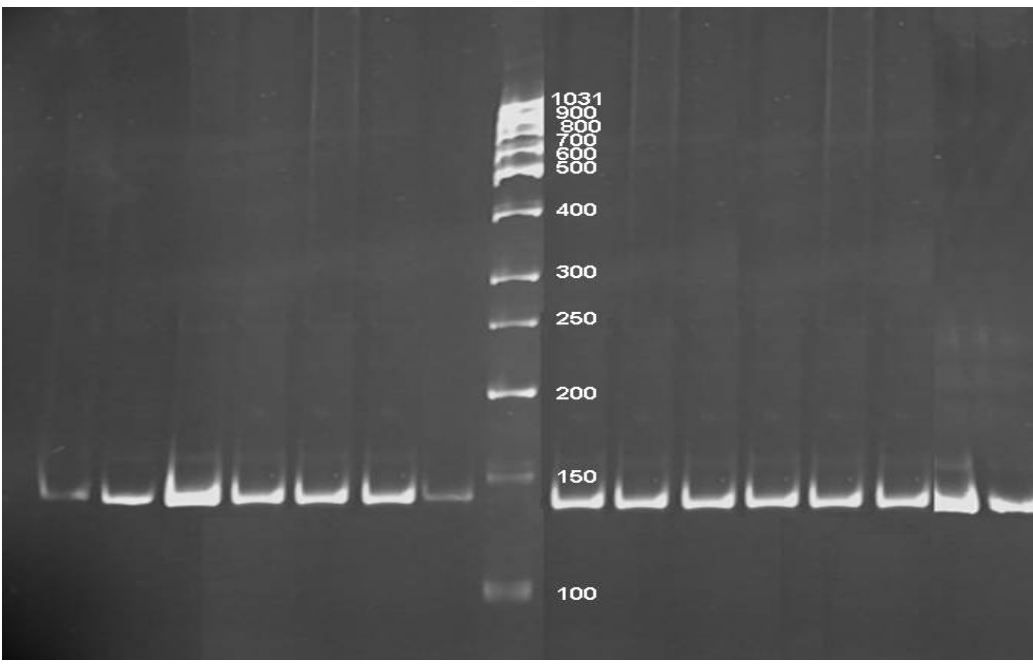

Fig. 8 Ethidium bromide stained polyacrylamide gel for the FBN13 microsatellite after running vertically

he similarities in chromosomal banding patterns between cattle and buffalo were shown in the genetic content either with type I or type II markers. Concerning type I markers which is a coding sequence mapped by in situ hybridization or somatic cell hybridization, great similarities were found in the chromosomal localization (for review see Iannuzzi, 1998). This similarity of the genetic content extended also to the type II markers such as microsatellites. Many reports indicate that the microsatellites are conserved between cattle and buffalo, and all the microsatellite PCR primers are working in buffalo (Moore et al., 1991; Pepin et al., 1995; Hassanane et al., 2000 and Moioli et al., 2001). It is well established that chromosome 6 in cattle carries many markers correlated with milk yield and milk constituents. Chromosome 7 in the buffalo is equivalent to chromosome 6 in cattle, so studying the genetic content for this chromosome will be helpful in understanding genes controlling milk and their contents in buffalos.

\section{CONCLUSIONS}

The results of the current study demonstrate that some cattle specific primers can be a valuable source for genome analysis in Bubaline species. Microsatellites BM143 and ILSTS093 are polymorphic in the Egyptian buffalo, so they are suggested for further productive genomic studies, such as gene mapping, marker-assisted selection, and genetic diversity in the Egyptian buffalo. Although ILSTS035, FBN13 and TGLA37 microsatellites are polymorphic markers in cattle, they did not show polymorphism in the present sample of Egyptian buffalo. 


\section{REFERENCES}

Arranz, J.J., Y. Bayon and F.S. Primitivo, 2001. Genetic variation at microsatellite loci in Spanish sheep. Small Ruminant Research. 39(1): 3-10.

Baruch, E., J.I. Weller. M. Cohen-Zinder, M. Ron and E. Seroussi, 2006. Efficient inference of haplotypes from genotypes on a large animal pedigree. Genetics. 172: 1757-1765.

Bhat, P.N.,1992.Genetics of river buffaloes. In: (eds) Tulooh, M. H. and Holmes, J. H. G. Buffalo production, production-system approach. Elsevier Scientific Publications ,Amsterdam, Netherlands .pp.13-52.

Bishop, M.D., S.M. Kappes, J.W. Keele, R.T. Stone, S.L. Sunden, G.A. Hawkins, S.S. Toldo, R. Fries, M.D. Grosz and J. Yoo, 1994. A genetic linkage map for cattle. Genetics. 136 (2): 619-39.

Chen, H.Y., Q. Zhang, C.C. Yin, C.K. Wang, W.J. Gong and G. Mei, 2006. Detection of quantitative trait loci affecting milk production traits on bovine chromosome 6 in a Chinese Holstein population by the daughter design. Journal of Dairy Science. 89: 782-790.

D’Angelo, F., E. Ciani, A. Sevi, M. Albenzio, R. Ciampolini and D. Cianci, 2006. The genetic variability of the Podolica cattle breed from the Gargano area. Preliminary results. Italian Journal of Animal Science. 5:79-85.

De Gortary, M.J., S.M. Freking, S.M. Kappes, K.A. Leymaster, A.M. Grawford, R.T. Ston and C.W. Beattie, 1997. Extensive genomice conservation of cattle microsatellite heterozygosity in sheep. Animal Genetics. 28: 274-290.

FAO, Food and Agriculture Organization of the United Nations, 2005. FAOSTAT online statistical service. FAO. http://www.fao.org

Freyer, G., C. Kühn, R. Weikard, Q. Zhang, M. Mayer and I. Hoeschele, 2002. Multiple QTL on chromosome six in dairy cattle affecting yield and content traits. Journal of Animal Breeding and Genetics. 119: 69-82.

Freyer, G., P. Sørensen, C. Kühn, R. Weikard and I. Hoeschele, 2003. Search for pleiotropic QTL on chromosome BTA6 affecting yield traits of milk production. Journal of Dairy Science. 86: 999-1008.

Freyer, G., P. Sørensen, C. Kühn and R. Weikard, 2004. Investigations in the character of QTL affecting negatively correlated milk traits. . Journal of Animal Breeding and Genetics. 121: 40-51.

Georges, M., and J. Massey, 1992. Polymorphic DNA markers in Bovidae. International patent application published under the patent cooperation treaty. WO 92/13102.

Georges, M., D. Nielson, M. Mackinnon, A. Mishra and R. Okimoto, 1995. Mapping quantitative trait loci controlling milk production in dairy cattle by exploiting progeny testing. Genetics. 139: 907-920.

Hassanane, M.S., M. Aasland, H. Klungland and D.I. Vage, 2000. Five bovine microsatellites showing polymorphism in river buffalo (Bubalus bubalis). Egyptian Jornal of Animal production ,37(2):77-84.

Hayden, M.J., and P.J. Sharp, 2001. Targeted development of informative microsatellite (SSR) markers. Nucleic Acids Research. 29(8): e44.

Iannuzzi, L., 1998: A genetic physical map in river buffalo (Bubalus bubalis, $2 \mathrm{n}=50$ ). Caryologia, 51 (3-4):311-318. 
Ihara, N., A. Takasuga, K. Mizoshita, H. Takeda, M. Sugimoto, Y. Mizoguchi, T. Hirano, T. Itoh, T. Watanabe, K.M. Reed, W.M. Snelling, S.M. Kappes, C.W. Beattie, G.L. Bennett and Y. Sagimoto, 2004. A comprehensive genetic map of the cattle genome based on 3802 microsatellites. Genome Research. 14:19871998

Kappes, S. M., J.W. Keele, R.T. Stone, R.A. Mc Graw, T.S. Sonstegard, T.P. Smith, N.L. Lopez-Corrales and C.W. Beattie, 1997. A second-generation linkage map of the bovine genome. Genome Research. 7 (3): 235-49.

Kemp, S. J., O. Hishida, J. Wambugu, A. Rink, M.L. Longeri, R.Z. Ma, Y. Da, H.A. Lewin, W. Barendse and A.J. Teale, 1995. A panel of polymorphic bovine, ovine and caprine microsatellite markers. Animal Genetics. 26 (5): 299-306.

Ma, R. Z., J.E. Beever, Y. Da, C.A. Green, I. Russ, C. Park, D.W. Heyen, R.E. Everts, S.R. Fisher, K.M. Overton, A.J. Teale, S.J. Kemp, H.C. Hines, G. Guérin, and H.A. Lewln, 1996. A male linkage map of the cattle (Bos taurus) Genome. The Journal of Heredity. 87: 261-271.

Mattapallil, M.J., and S. Ali, 1999. Analysis of conserved microsatellite sequences suggests closer relationship between water buffalo Bubalus bubalis and sheep Ovis Aries (Abstract). DNA Cell Biology. 18 (6).

Maudet, C., A. Beja-Pereira, E. Zeyl, H. Nagash, A. Kence, D. Özüt, M.P. BijuDuval, S. Boolormaa, D.W. Coltman, P. Taberlet and G. Luikart, 2004. A standard set of polymorphic microsatellites for threatened mountain ungulates (Caprini,Artiodactyla). Molecular Ecology Notes. 4 :49-55.

Moioli, B., A. Georgoudis, F. Napolitano, G. Cattilo, E. Giubilei, C.h. Ligda and M. Hassanane, 2001. Genetic diversity between Italian, Greek and Egyptian buffalo populations. Livestock Production Science:70(3):203-211.

Moore, S.S., L.L. Sargeant, T.L. King, J.S. Mattick, M. Georges and D.J.S. Hetzel, 1991. The conservation of dinucleotide microsatellites among mammalian genomes allows the use of heterologous PCR primer pairs in closely related species, Genomics 10: 654-660 .

Navani, N., P.K. Jain, S. Gupta, B.S Sisodia and S. Kumar, 2002. A set of cattle microsatellite DNA markers for genome analysis of riverine buffalo (Bubalus bubalis). Animal Genetics. 33 (2): 149-154.

Olsen, H.G., L. Gomez-Raya, D.I. Våge, I. Olsaker, H. Klungland, M. Svendsen, T. Ådnøy, A. Sabry, G. Klemetsdal, N. Schulman, W. Krämer, G. Thaller, K. Rønningen and S. Lien, 2002. A genome scan for quantitative trait loci affecting milk production in Norwegian dairy cattle. Journal of Dairy Science.85: 31243130.

Olsen, H.G., S. Lien, M. Svendsen, H. Nilsen, A. Roseth, M Aasland Opsal and T.H.E. Meuwissen, 2004. Fine mapping of milk production QTL on BTA6 by combined linkage and linkage disequilibrium analysis. Journal of Dairy Science. 87: 690-698.

Othman, O.E., and S. El Nahas, 1998. Synteny assignment of four genes and two microsatellite markers in river buffalo (Bubalus bubalis L.). Journal of Animal Breeding and Genetics. 116: 161-168.

Pepin, L., Y. Amigues, A. Lepingle, J.L. Berthier, A. Bensaid and D. Vaiman, 1995. Sequence conservation of microsatellites between Bos taurus (cattle), Capra hircus (goat) and related species. Examples of use in parentage testing and phylogeny analysis. Heredity 74: 53-61. 
Peter, R., R. Monika, M. Uwe and A. Salah, 2005. Fine mapping of milk yield QTL on chromosomes 6 and 20 in German Holstein population using microsatellite markers. Journal of Central European Agriculture. 6 (4): 501-508.

Ron, M., D. Kliger, E. Feldmesser, E. Seroussi, E. Ezra and J.I. Weller, 2001. Multiple QTL analysis of bovine chromosome 6 in the Israeli Holstein population by a daughter design. Genetics. 159: 727-735.

Sambrook, J., E.F. Fritsch and T. Maniatis, 1989. Molecular cloning: a laboratory manual. Cold Spring Harbor Laboratory Press, New York, USA.

Spelman, R.J., W. Coppieters, L. Karim, J.M. Van Arendonk and H. Bovenhuis, 1996. Quantitative trait loci analysis for five milk production traits on chromosome six in the Dutch Holstein-Friesian population. Genetics. 144(4): 1799-1808.

Schnabel, R.D, J. Kim, M.S. Ashwell, T.S. Sonstegard, C.P. Van Tassell, E.E. Connor, and J.F.Taylor, 2005. Fine-mapping milk production quantitative trait loci on BTA6:Analysis of the bovine osteopontin gene 102 :(19) 6896-6901

Soysal, M. İ., E. Özkan, S. Kök, Y.T.Tuna, E.K.Gürcan, 2005. Genetic Characterization of Indigenous Anatolian Water Buffalo Breed Using Microsatellite DNA Markers. Journal of Tekirdag Agricultural Faculty 2:(3) 240243

Vallejo, R.L., Y.L. Li, G.W. Rogers and M.S. Ashwell, 2003. Genetic diversity and background linkage disequilibrium in the North American Holstein cattle population. Journal of Dairy Science. 86: 4137-4147.

Van Hooft, W.F., O. Hanotte, P.W. Wenink, A.F. Groen, Y. Sugimoto, H.H.T. Prins and A. Teale, 1999. Applicability of bovine microsatellite markers for population genetic studies on African buffalo (Syncerus caffer). Animal Genetics. 30: 214220.

Weikard, R., T. Goldammer, C. Kuhn, W. Barendse and M. Schwerin, 1995. Targeted development of microsatellite markers from the defined region of bovine chromosome 6q21-31. Mammalian Genome. 8 :(11) 836-40.

Yeo, J., J. Lee and J. Kim, 2004. DNA marker mining of ILSTS035 microsatellite locus on chromosome 6 of Hanwoo cattle. Journal of Genetics. 83: (3) 245-250.

Yoneda, K., Y. Moritomo, M. Takami, S. Hirata, Y. Kikukawa and T. Kunieda, 1999. Localization of a locus responsible for the bovine chondrodysplastic dwarfism (bcd) on chromosome 6. Mammalian Genome. 10: (6) 597- 600. 


\section{تعدد المظاهر الوراثية لبصض التوابع الوراثية الاقيقة على الكروموسوم السابع في

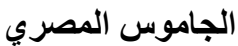
محمد صابر حسانين، أحمد عبد الصمد زكي، سامي أبو بكر²، ربيع رجب صادق، علي عطية

1- قسم بيولوجيا الخلية، المركز القومي للبحوث، الدقي، الجيزة، مصر، 2- قسم الإنتاج الحيو اني كلية

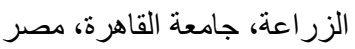

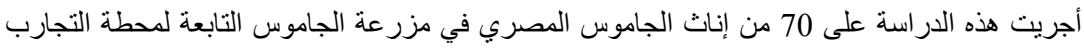

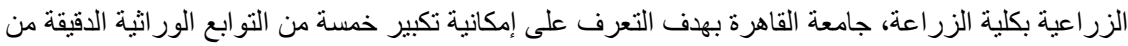

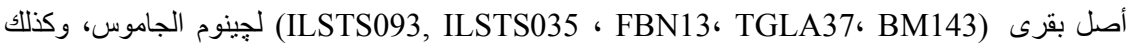

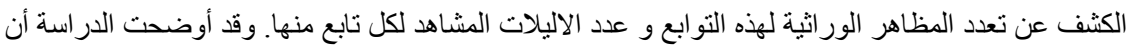

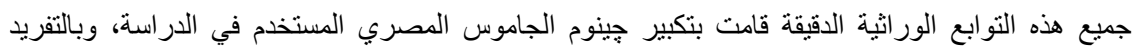

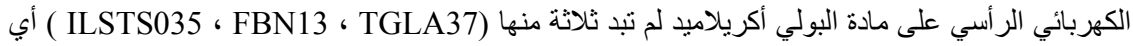

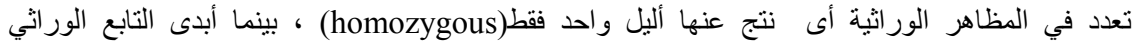

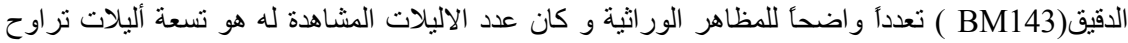

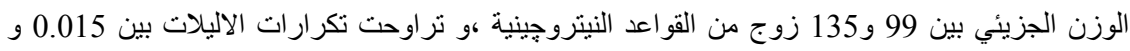

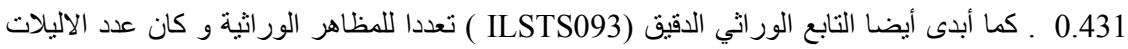

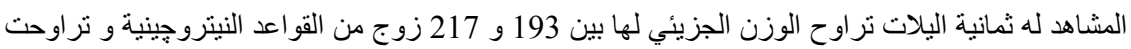

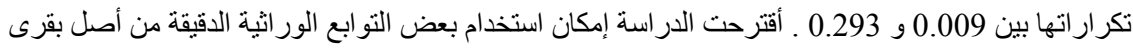

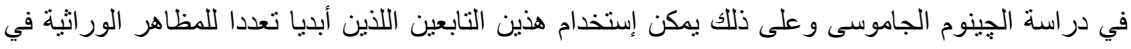

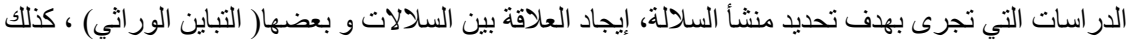

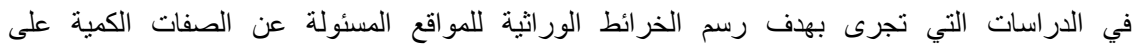
الجينوم( QTLs ) في الجاموس المصري. 